Jurnal Mandala Pharmacon Indonesia, Vol 4.No.1 Juni 2018

Avaiable online at www.jurnal-pharmaconmw.com/jmpi

$p$-ISSN : 2442-6032

e-ISSN : 2598-9979

\title{
Efek Hepatoprotektor Ekstrak Terpurifikasi Batang Galing (Cayratia trifolia L.Domin) Pada Tikus Putih Wistar Jantan (Rattus noervegicus)
}

\author{
Muhammad Ilyas Yusuf1, Selfyana Austin Tee ${ }^{2}$, Karmila², Asriullah Jabbar ${ }^{3}$ \\ 1Prodi DIII Analis Kesehatan, Politeknik Bina Husada Kendari, JL.Sorumba No.17 Kota Kendari \\ ${ }^{2}$ Prodi DIII Farmasi, Politeknik Bina Husada Kendari, Indonesia. \\ 3Jurusan Farmasi, Fakultas Farmasi Universitas Halu Oleo Kendari, Indonesia.
}

\begin{abstract}
ABSTRAK
Hepatoprotektor adalah suatu senyawa yang dapat memberikan perlindungan pada hati dari kerusakan hati. Salah satu cara untuk mengetahui fungsi hati dengan mengukur aktivitas enzim Serum Glutamic Oxaloacetic Transaminase (SGOT) dan Serum Glutamic Pyruvic Transaminase (SGPT). Salah satu bahan alam yang berpotensi memiliki efek hepatoprotektor adalah tumbuhan Galing dan telah dilakukan penelitian bahwa tumbuhan galing mengandung senyawa flavonoid yang berpotensi sebagai antioksidan. Tujuan penelitian untuk mengetahui efek hepatoprotektor dari ekstrak terpurifikasi batang galing dosis $400 \mathrm{mg} / \mathrm{kgBB}$ pada tikus wistar jantan setelah diinduksi Paracetamol dosis toksik. Jenis penelitian adalah eksperimental laboratorium, dengan desain pre and post test control group design dan menggunakan 12 ekor tikus putih yang dibagi dalam 3 kelompok perlakuan dengan empat
\end{abstract}

\section{PENDAHULUAN}

Penyakit hati merupakan salah satu penyakit di Indonesia yang mempunyai prevalensi yang cukup tinggi. Menurut data WHO, pada tahun 2012 virus hepatitis B telah menginfeksi 2 miliar penduduk dunia. Hepatitis atau radang hati dapat disebabkan oleh berbagai faktor, seperti virus, bakteri, parasit, obat-obatan, alkohol, cacing, atau gizi buruk (Ulfa, 2008). kali pengulangan yang diinduksi dengan paracetamol dosis toksik setelah pemberian ekstrak. Berdasarkan hasil penelitian menunjukkan bahwa pemberian ekstrak terpurifikasi batang galing dengan dosis $400 \mathrm{mg} / \mathrm{kgBB}$, memberikan efek hepatoprotektor yang efektif terhadap peningkatan kadar SGPT setelah diinduksi paracetamol dosis toksik

Kata kunci : Hepatoprotektor, Purifikasi, Batang galing, SGOT, SGPT, Rattus novergicus

Penulis korespondensi :

Muhammad Ilyas Yusuf

Prodi DIII Analis Kesehatan, Politeknik Bina Husada Kendari

E-mail : ilyasyusufmuhammad.apt@gmail.com

Tujuan pengobatan penyakit hepar adalah mengurangi peradangan hati dengan cara menghilangkan atau menekan replikasi virus penyebab kerusakan hati sehingga tidak berlanjut. Sampai saat ini belum ada terapi yang optimal serta biaya terapi mahal, efek samping yang serius dan tidak dapat mencegah rekurensi penyakit, maka para ahli mencoba terapi alternatif seperti terapi herbal (Merinda, 2014). Salah satu obat herbal yang sering 
digunakan ialah tumbuhan galing penelitian golongan senyawa kimia daun dan batang yaitu memiliki kandungan kimia karbohidrat, lignin, steroid, sterol, polifenol, polifenol, flavanoid, glikosida (Gupta j \& Gupta A, 2012). Berdasarkan penelitian yang dilakukan oleh Rumayanti dkk, 2014 yaitu aktivitas antioksidan paling besar ada pada fraksi metanol batang tumbuhan galing berdasarkan penapisan fitokimia, senyawa yang berperan terhadap aktivitas antioksidan diperkirakan dari golongan flavanoid.

Namun pada beberapa penelitian senyawa aktif dalam ekstrak masih dipengaruhi oleh beberapa senyawa pengotor (yang tidak berkhasiat) sehingga perlu dilakukan penelitian yang menghilangkan senyawa pengotor dengan metode purifikasi ekstrak. Ekstrak terpurifikasi merupakan ekstrak yang telah terbebas dari komponen zat ballast yang dapat mengganggu suatu matriks bahan alam dalam menghasilkan aktivitas biologi (Widyaningtias dkk, 2014).

Penelitian yang dilakukan bertujuan untuk menguji efek hepatoprotektor dari ekstrak terpurifikasi batang galing tikus wistar jantan setelah pemberian Paracetamol dosis toksik. Hasil penelitian ini diharapkan dapat memberikan informasi ilmiah kepada masyarakat mengenai efek ekstrak terpurifikasi batang galing (Cayratia trifolia L. Domin) sebagai hepatoprotektor.

\section{METODOLOGI PENELITIAN}

A. Jenis Penelitian, Waktu, dan Tempat Jenis penelitian yang digunakan adalah penelitian eksperimen, dengan Desain penelitian yang digunakan dalam penelitian ini yaitu pre and post test control group design menggunakan 12 ekor tikus galur wistar yang dibagi dalam 3 kelompok perlakuan, tiap kelompok terdiri dari kelompok kontrol negatif, kontrol positif, dan kelompok ekstrak $400 \mathrm{mg} / \mathrm{kg}$ BB selama 14 hari dengan kadar SGPT dan SGOT. Penelitian ini dilaksanakan bulan Juni 2017 di Laboratorium Farmakologi Akademi Farmasi Bina Husada Kendari dan Laboratorium RS. PMI Kendari

B. Alat dan Bahan Penelitian

Alat-alat yang digunakan pada penelitian ini adalah Fotometer 5010, timbangan analitik $\left(\right.$ Precisa $^{\circledR}$ ), gelas ukur (pyrex), gelas kimia (pyrex), pipet ukur, pipet mikro, sentrifuge, stopwatch, tabung reaksi $\left(\right.$ Pyrex $\left.^{\circledR}\right)$, tabung sentrifuge $\left(\right.$ Pyrex $^{\circledR}$ ) gelas kimia $\left(\right.$ Pyrex $\left.^{\circledR}\right)$, spoit oral (kanula) dan spoit injeksi. Bahan yang digunakan: alkohol 96\%, N-heksan, akuadest,,reagen GPT (alat), reagen GOT (asat), serbuk paracetamol, serbuk temulawak,Na CMC 0,5\%, N-heksan, dan Na EDTA 10\%. 
C. Penyiapan dan pembuatan batang galing

Sampel batang galing dibersihkan, dirajang, dikeringkan dan diekstraksi dengan metode maserasi menggunakan pelarut etanol 96\% selama 5 hari. Ekstrak cair dipekatkan menggunakan rotavapor.

D. Pembuatan ekstrak terpurifikasi

Ekstrak kental dilarutkan dengan etanol dan dimasukkan dalam corong, kemudian ditambahkan N-heksan dengan perbandingan 1:1 setelah itu dikocok selama 5 menit dan didiamkan selama 15 menit ambil lapisan N-heksan. Lakukan pengulangan diatas hingga fase etanol berwarna bening kemudian diuapkan dalam waterbath.

E. Pengujian Efek hepatoprotektor pada Hewan Uji

Terdiri dari 4 ekor tikus wistar dengan 3 kelompok perlakuan, hewan uji dipuasakan 6-8 jam sebelum perlakuan, kemudian ditimbang. Diambil darah tikus wistar melalui intra muscular melalui ekor dengan menggunakan spoit $1 \mathrm{cc}$, disentrifug lalu ukur SGOT dan SPGT awal. Kemudian hewan uji pada kelompok I yaitu kelompok perlakuan diberi ekstrak terpurifikasi batang galing (Cayratia trifolia L. Domin) dengan dosis $400 \mathrm{mg} / \mathrm{kgBB}$, kelompok II yaitu kelompok kontrol positif diberikan serbuk temulawak, kelompok III yaitu kelompok kontrol negatif diberikan Na. CMC 0,5\%. Ketiga kelompok tersebut diberi perlakuan (1 kali sehari) selama 6 hari lalu dilakukan pengukuran kadar SGOT/SPGT pertama pada hari ke-7, dan diberi perlakuan diinduksi dengan paracetamol 2,5g/kgBB (1 kali sehari) pada hari ke-8 sampai hari ke-13, dan pada hari ke-14 dilakukan pengukuran aktifitas SGOT dan SPGT akhir.

F. Analisis Data

Pengolahan data yang digunakan dalam penelitian ini adalah uji anova dilanjutkan uji BNT pada tingkat kepercayaan $95 \% \quad(=0,05) \quad$ dengan menggunakan SPSS 20

\section{HASIL DAN PEMBAHASAN}

Zat penginduksi hepatotoksik yang digunakan dalam penelitian ini adalah adalah parasetamol, pemberian parasetamol dosis tinggi diberikan setiap hari agar menyebabkan kerusakan pada hati. Paracetamol yang mempunyai daya hepatotoksik sangat besar apabila digunakan dalam dosis tunggal yaitu 10-15 g (Goodman dan Gilman, 2007). Rata-rata pengukuran kadar SGOT maupun SGPT pada hewan uji tikus putih setelah pemberian ekstrak memiliki kadar yang normal (SGOT pada darah tikus putih yaitu 30,2-45,7 $\mu$ /L dan kadar SGPT yaitu 17,5-30,2 $\mu / \mathrm{L}$ ) (Smith \& Mangkoewidjojo, 
1988). Dalam penelitian ini tikus putih melindungi hepar. Berdasarkan hasil diberi ekstrak selama 7 hari dengan tujuan penelitian yang dilakukan dari masinguntuk mengetahui sejauh mana ekstrak masing kelompok diperoleh data sebagai terpurifikasi batang galing dapat berikut

Tabel 1. Kadar SGOT dan SGPT setelah pemberian ekstrak dan pemberian paracetamol dosis toksik

\begin{tabular}{|c|c|c|c|c|c|c|}
\hline \multirow[t]{2}{*}{ No } & \multirow[t]{2}{*}{ Perlakuan } & \multirow[t]{2}{*}{$\begin{array}{l}\text { Hewa } \\
\mathrm{n} \text { uji } \\
\text { tikus }\end{array}$} & \multicolumn{2}{|c|}{$\begin{array}{c}\text { Kadar Setelah } \\
\text { Pemberian Ekstrak } \\
(\mu / \mathrm{L})\end{array}$} & \multicolumn{2}{|c|}{$\begin{array}{c}\text { Kadar Setelah Induksi } \\
\operatorname{PCT}(\mu / L)\end{array}$} \\
\hline & & & SGOT & SGPT & SGOT & SGPT \\
\hline \multirow{5}{*}{1} & Serbuk & 1 & 26 & 20 & 27 & 19 \\
\hline & temulawak & 2 & 17 & 17 & 30 & 25 \\
\hline & (Kontrol & 3 & 25 & 22 & 26 & 20 \\
\hline & positif + PCT) & 4 & 22 & 21 & 25 & 18 \\
\hline & Rata-rata & & 22,5 & 20 & 27,26 & 20,25 \\
\hline \multirow{5}{*}{2} & & 1 & 32 & 26 & 40 & 40 \\
\hline & $\mathrm{Na}$ CMC & 2 & 30 & 29 & 43 & 38 \\
\hline & (Kontrol & 3 & 28 & 27 & 38 & 42 \\
\hline & negatif $+P C \mid$ ) & 4 & 29 & 25 & 41 & 35 \\
\hline & Rata-rata & & 29,75 & 26,75 & 40,5 & 38,75 \\
\hline \multirow{5}{*}{3} & Ekstrak & 1 & 26 & 20 & 32 & 25 \\
\hline & Batang 400 & 2 & 23 & 25 & 37 & 23 \\
\hline & $\mathrm{mg} / \mathrm{kgBB}+$ & 3 & 21 & 24 & 28 & 21 \\
\hline & PCT & 4 & 25 & 18 & 30 & 30 \\
\hline & Rata-rata & & 23,75 & 21,75 & 31,75 & 24,75 \\
\hline
\end{tabular}

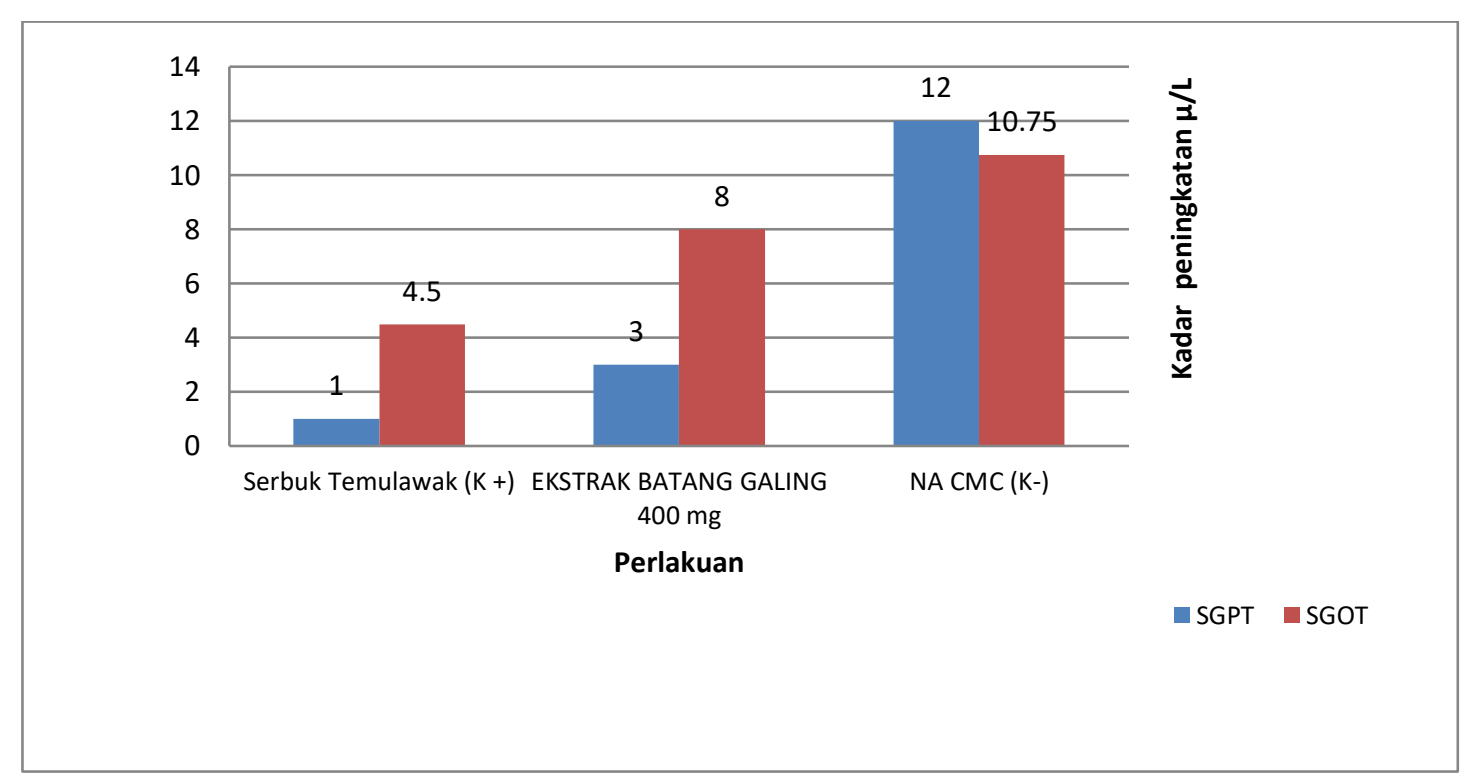

Diagram 1. Kadar peningkatan SGOT dan SGPT setelah pemberian ekstrak dan induksi paracetamol dosis toksik. 
Kelompok negatif setelah pemberian parasetamol selama 5 hari pada hari ke-14 mengalami peningkatan kadar yaitu 10,75 $(\mu / \mathrm{L})$ dan SGPT sebesar $12(\mu / \mathrm{L})$. Berdasarkan hasil tersebut, menunjukkan bahwa parasetamol dapat mengakibatkan kerusakan hati ditandai dengan adanya peningkatan kadar SGPT dan SGOT. Hal ini dikarenakan pada pemberian parasetamol dosis tinggi akan Terbentuknya metabolit antara NAPQI dalam jumlah banyak dan penurunan glutathion hati akan berakibat terjadi nekrosis atau kerusakan hati. Sel-sel hati yang rusak akan melepaskan enzim-enzim yang menandai kerusakan tersebut yaitu SGOT dan SGPT (Husadha, 1999).

Kelompok positif terjadi peningkatan kadar setelah pemberian parasetamol yaitu SGOT sebesar 4,5 $(\mu / \mathrm{L})$ dan SGPT sebesar $1(\mu / \mathrm{L})$ peningkatan kadar SGOT dan SGPT lebih rendah jika dibandingkan dengan kelompok negatif. Kurkumin terbukti mampu meningkatkan muatan glutathion hati sehingga kebutuhannya untuk berkonjugasi dengan NAPQI akan terpenuhi dan tidak terjadi ikatan NAPQI dengan makromolekul hepatosit (Stoner dan Mukhtar, 1995).

Kelompok perlakuan ekstrak terpurifikasi batang galing (Cayratia trifolia L. Domin) pada peningkatan kadar tidak berbeda jauh dengan kontrol positif dapat memperbaiki dan mempercepat sel-sel hati yang rusak. Aktivitas hepatoprotektif yang ditunjukkan oleh ekstrak terpurifikasi batang galing kemungkinan disebabkan oleh adanya aktivitas antioksidan dalam tanaman tersebut. Oleh karena itu pemberian ekstrak terpurifikasi batang galing terbukti secara signifikan melalui statistik mempunyai aktivitas hepatoprotektif terhadap hati tikus yang dipapar paracetamol dosis toksik.

untuk mengetahui melihat kesamaan satu perbedaan rata-rata selisih pada kelompok perlakuan test pengujian Anova menunjukkan hasil yang signifikan dimana ekstrak yang diberikan memiliki efek pada hewan uji.

Dari hasil uji LSD/BNT (Beda Nyata Terkecil) untuk kadar SGOT pada pengujian Anova menunjukkan hasil yang signifikan, sehingga dilanjutkan dengan pengujian LSD/BNT (Beda Nyata Terkecil) diperoleh hasil yang berbeda secara signifikan untuk ekstrak terpurifikasi batang galing , dimana ekstrak terpurifikasi batang galing memiliki efek tetapi efeknya tidak sama dengan kontrol positif.

Berdasarkan hasil statistik menunjukkan perbedaan hasil dari 
pengujian SGOT dan SGPT, dimana pada pengukuran kadar SGOT menunjukkan bahwa efek ekstrak terpurifikasi berbeda secara signifikan dengan kontrol positif sedangkan untuk pengukuran kadar SGPT menunjukkan hasil yang tidak berbeda secara signifikan artinya bahwa ekstrak terpurifikasi batang galing memberikan efek yang sama dengan kontrol positif. Menurut Ferina (2014) yaitu gangguan fungsi hati terpenting adalah peningkatan enzim transaminase hati terutama serum SGPT. Tingginya kadar SGPT menggambarkan berat ringannya proses nekroinflamasi. Jadi enzim SGOT tidak spesifik terhadap kerusakan sel hati karena enzim SGOT juga terdapat pada otot jantung, otot tubuh, ginjal dan pankreas, sedangkan enzim SGPT sangat spesifik terhadap sel-sel hati. Dimana penentuan aktivitas ALT atau SGPT dianggap sebagai tes yang lebih sensitive dan spesifik terhadap adanya kerusakan hepatoseluler akut. Jadi, apabila ekstrak terpurifikasi batang galing dapat memberikan peningkatan kadar SGPT yang sama dengan kontrol positif sudah dikatakan bersifat sebagai hepatoprotektor. Berdasarkan hasil statistik menunjukkan perbedaan hasil dari pengujian SGOT dan SGPT, dimana pada pengukuran kadar SGOT menunjukkan bahwa efek ekstrak terpurifikasi berbeda secara signifikan dengan kontrol positif sedangkan untuk pengukuran kadar SGPT menunjukkan hasil yang tidak berbeda secara signifikan artinya bahwa ekstrak terpurifikasi batang galing memberikan efek yang sama dengan kontrol positif. Menurut Ferina (2014) yaitu gangguan fungsi hati terpenting adalah peningkatan enzim transaminase hati terutama serum SGPT. Tingginya kadar SGPT menggambarkan berat ringannya proses nekroinflamasi. Jadi enzim SGOT tidak spesifik terhadap kerusakan sel hati karena enzim SGOT juga terdapat pada otot jantung, otot tubuh, ginjal dan pankreas, sedangkan enzim SGPT sangat spesifik terhadap sel-sel hati.

\section{KESIMPULAN}

Ekstrak terpurifikasi batang galing dosis $400 \mathrm{mg} / \mathrm{kgBB}$ memberikan efek Hepatoprotektor pada tikus putih wistar jantan yang diinduksi paracetamol dosis toksik berdasarkan kadar rata-rata SGOT dan SGPT tikus putih, dimana kadar ratarata SGOT darah tikus putih setelah pemberian ekstrak terpurifikasi batang galing $400 \mathrm{mg} / \mathrm{kgBB}$ berbeda signifikan dengan kontrol positif serbuk temulawak. 


\section{DAFTAR PUSTAKA}

Ari Diana Susanti, Dwi Ardiana, Gita Gumelarp, Yosephin Bening G. 2012. Polaritas Pelarut Sebagai Pertimbangan Pemilihan Pelarut Untuk Ekstraksi Minyak Bekatul Varietas Ketan (Oriza Sativa Glatinosa) ISSN : 1421-9612 Hal. 8-14

Goodman \& Gilman. 2007. Dasar-dasar Farmakologi Terapi. EGC : Jakarta Gupta J kumar D, Gupta A. 2012. Evaluation Of Gastric Anti-Ulcer Activity of Methanolic Extract Of Cayratia trifolia In Experimental Animals. Asian pac J Dis 2012;2;99-102

Husadha, Y., 1999, Buku Ajar Ilmu Penyakit Dalam; Jilid I, Gaya Baru, Jakarta, hal. 226-227.

Merinda, D. 2014 , 'Hepatoprotective Effect Of Curcumin In Chronic Hepatitis'. Faculty of Medicine, Lampung University, Vol.3, No.7, 2014 : 52-56

Stoner, G.D. and H. Mukhtar. 1995. Polyphenols as Cancer Chemopreventive Agents_A Review

Ulfa, M. 2008, 'Efek Hepatoprotektif Ekstrak Etil Asetat Daun Sambung Nyawa (Gynura procumbens lour.) Terhadap Mencit Jantan Galur Swiss Terinduksi Parasetamol',Fakultas Farmasi, Universitas Muhammadiyah Surakarta, Surakarta Widyaningtias,N.M.S.R.,Yustiantara, P.S., Paramita, N.L.P.V. 2014, 'Uji Aktivitas
Antibakteri Ekstrak Terpurifikasi Daun sirih hijau (Piper betle L.) Terhadap Bakteri Propionibacterium acnes. Jurusan Farmasi Fakultas Matematika dan Ilmu Pengetahuan Alam Universitas Udayana 